\title{
Perancangan Komik Edukasi Industri Kimia Sebagai Media Pengantar untuk Mahasiswa Baru Teknik Kimia
}

\author{
Hedi Amelia Bella Cintya dan Sayatman \\ Departemen Desain Produk, Fakultas Arsitektur Desain dan Perencanaan, \\ Institut Teknologi Sepuluh Nopember (ITS) \\ e-mail: bellacintya@gmail.com, sayatasik@prodes.its.ac.id
}

\begin{abstract}
Abstrak-Industri Proses Kimia adalah ilmu industri yang mengolah bahan baku menjadi suatu hasil atau produk dengan memanfaatkan proses-proses kimia. Di ITS terdapat pula mata kuliah yang mempelajari Industri proses kimia, yaitu Pengantar Industri kimia. Kendala yang ada, buku-buku referensi untuk mata kuliah Pengantar Industri Kimia ini minim visual dan dominan dengan rumus, huruf, serta angka dalam berates-ratus halaman. Dibutuhkan sebuah media yang menyenangkan dan dapat memacu motivasi belajar. Dari wawancara yang dilakukan penulis, beberapa mahasiswa mengaku kesulitan memahami materi dengan buku-buku tersebut. Hal ini juga berpotensi menimbulkan kesan bahwa ilmu industri kimia susah dipahami, dan minat terhadap ilmu kimia bisa menurun. Dibutuhkan sebuah media pengenalan sekaligus pengantar yang dapat mematahkan persepsi negatif terhadap ilmu industti kimia. Media komik edukasi adalah media yang berpotensi untuk menjadi solusi, karena media ini memiliki sifat sederhana, jelas, mudah dipahami, dan lebih bersifat personal sehingga informatif dan edukatif. Perancangan ini menggunakan beberapa metode riset untuk mengetahui preferensi komik target audience dan materi industri kimia minyak bumi. Penulis mencari rumusan yang tepat dalam menggabungkan media komik dengan materi kimia agar dapat diterima dengan baik oleh pembaca dewasa muda usia 18-22 tahun. Salah satu caranya adalah dengan menggunakan infografis sebagai metode penyampaian materi dalam komik. Hasil konsep perancangan ini adalah komik edukasi minyak bumi sebagai media pengantar untuk mahasiswa baru teknik kimia yang edukatif, informatif, dan komunikatif. Diharapkan dengan adanya buku komik edukasi ini, mahasiswa dapat memahami ilmu industri kimia dengan lebih mudah dan calon mahasiswa dapat mengenal industri kimia dengan media yang lebih informatif, edukatif, dan menyenangkan.
\end{abstract}

Kata Kunci- komik, edukasi, industri, petroleum, kimia.

\section{PENDAHULUAN}

$\mathrm{M}$ ATA kuliah Pengantar Industri Kimia biasanya diajarkan di tahun pertama jurusan Teknik kimia. Di ITS sendiri, mata kuliah Pengantar Industri Kimia diberikan pada semester 2. Terdapat 2 pustaka utama untuk mata kuliah ini, yakni "Shreve's Chemical Process Industries" (1985) tulisan George T. Austin, dan "Elementary Principles of Chemical Process" (2005) susunan R.M. Felder dan R.W. Rosseau. Setelah dilakukan analisis artefak, ditarik kesimpulan bahwa kedua buku referensi sama-sama dominan dengan huruf dan angka. Terdapat beberapa visual pendukung, namun hanya untuk menggambarkan sedikit dari materi yang dijelaskan di buku serta bersifat lugas. Warna halaman tidak full colour. Saya melakukan wawancara kecil dengan Bapak Juwari, Kepala Departemen Teknik Kimia ITS, yang mengaku bahwa buku-buku referensi memang kebanyakan kurang menarik secara visual; isi bukunya hanya berupa tulisan dan rumus dalam berates-ratus bahkan beribu halaman.

Buku referensi yang dianggap kurang memacu motivasi belajar mahasiswa oleh stakeholder merupakan suatu kendala yang harus diselesaikan segera supaya tidak muncul persepsipersepsi negatif yang akan membatasi semangat mahasiswa dalam mempelajari Industri Kimia.

Oleh karena itu, dibutuhkan sebuah media pembelajaran yang memiliki banyak aspek visual tetapi tetap edukatif, menyenangkan, dan diharapkan dapat memacu motivasi belajar mahasiswa - seperti media komik edukasi, karena dalam berbagai hal komik dapat diterapkan untuk menyampaikan pesan berbagai ilmu pengetahuan, dan karena penampilannya yang menarik, format dalam komik ini seringkali diberikan pada penjelasan yang sungguh-sungguh daripada sifat yang hiburan semata-mata. Buku-buku komik dapat dipergunakan secara efektif oleh guru-guru dalam usaha membangkitkan minat, mengembangkan perbendaharaan katakata dan keterampilan membaca, serta memperluas minat baca [1].

\section{A. Rumusan Masalah}

"Bagaimana membuat sebuah buku komik edukasi yang dapat menjadi media pengantar Industri Teknik Kimia Minyak Bumi yang menyenangkan untuk Mahasiswa Baru Teknik Kimia?"

\section{B. Batasan Masalah}

1. Komik dibuat dengan tujuan untuk menyajikan ilmu Industri Kimia Minyak Bumi untuk dewasa muda usia 18-22 tahun, terutama yang berstatus Mahasiswa Teknik Kimia (target utama) dan siswa SMA kelas 3 (target sekunder).

2. Sampel Studi kasus utama dalam perancangan ini mencakup Mahasiswa Teknik Kimia ITS

\section{Tujuan Penelitian}

Menyusun sebuah buku komik edukasi Kimia yang menyenangkan untuk dewasa muda usia 18-22 tahun tertuama yang berstatus sebagai mahasiswa baru Teknik Kimia, yang nantinya akan dipublikasikan secara luas di pasar. 


\section{KAJIAN PUSTAKA}

\section{A. Tinjauan Hasil Desain/Riset Terdahulu}

Dilakukan tinjauan terhadap 2 komik edukasi yang sudah dipublikasikan dan beredar di toko buku. Kedua buku tersebut ialah "WHY? Utopia Thomas Moore" karya Seokho JEONG dan Namseon YOON, serta buku "3 Menit Belajar Pengetahuan Umum: Tokoh Penemu, Tubuh Kita, Lingkungan" karya Kim Seok-Ho dan Kim Seok-Cheon. Dari tinjauan tersebut, ditarik kesimpulan bahwa kedua buku memiliki gaya gambar kartun, full colour, dan menggunakan visual beragam untuk menyampaikan materi utama. Perbedaan ada pada alur cerita, "WHY?" menggabungkan materi utama dengan cerita, sementara "3 Menit" menggunakan cerita pendek per 2 halaman untuk membahas topik yang berbedabeda.

\section{B. Ilmu Industri Kimia Minyak Bumi}

Topik utama dari perancangan ini ialah komik edukasi industri kimia minyak bumi, sehingga perlu dilakukan riset mengenai materi minyak bumi. Riset dilakukan dengan mempelajari buku-buku kimia yang ditunjuk oleh stakeholder untuk dijadikan rujukan. Buku tersebut ialah "Teknologi Minyak Bumi" karangan A. Hardjono [2]. Buku ini memiliki daftar konten yang cukup mudah dipahami bahkan untuk orang awam, dan buku seluruhnya menggunakan bahasa Indonesia. Buku berjumlah 207 halaman, lumayan tipis apabila dibandingkan dengan buku pembelajaran industri kimia yang berjumlah lebih dari 500 halaman.

\section{Komik Sebagai Media Edukasi}

Dr. Nana Sudhana dan Drs. Ahmad Rivai menyebutkan, bahwa buku teknik komik dapat diterapkan kepada berbagai lapangan pengetahuan - hal ini disebabkan karena penampilannya luas. Peranan pokok dari buku komik dalam pengajarannya adalah kemampuannya dalam menciptakan minat para siswa [1]. Banyak pengalaman orang tua, buku (bukan komik) yang dibelikan untuk anak hanya dibaca beberapa halaman, kemudian ditinggal di lemari. Anak-anak sekarang lebih gemar menonton televisi dan bermain telepon genggam sehingga malas untuk membaca buku yang penuh dengan kata-kata [3].

Penelitian relevan mengenai penggunaan komik sebagai media edukasi untuk mahasiswa pernah dilakukan sebelumnya oleh Triani Ratnawuri, S.Pd., M.Pd. [4]. Hasil penelitian menyebutkan bahwa kelas eksperimen yang mendapatkan perlakuan (menggunakan komik sebagai media pembelajaran) mengalami peningkatan rata-rata nilai sebesar $22,79 \%$, perbedaan yang signifikan apabila dibandingkan dengan kelas yang tidak mendapat perlakuan.

\section{Elemen Komik}

Menurut buku "Belajar Menggambar Komik Jepang" karya Gakushudo [5], disebutkan elemen-elemen dalam komik adalah:

1. Karakter, mencakup protagonist, antagonis, dan tokoh pendukung. Karakter utama biasanya mempunyai karakteristik yang lebih menonjol dari karakter tambahan.

2. Tema/Cerita, adalah ide yang ingin disampaikan kepada pembaca.

3. Storyboard, adalah pengaturan panel-panel berdasarkan alur cerita, membuat sketsa kasar dan merencanakan dialog.

4. Panel, pengaturan panel sangat penting agar pembaca tidak bingung ketika membaca komik.

5. Balon dialog, merupakan representasi ucapan yang dimuat dalam gambar berbentuk gelembung.

\section{METODE PENELITIAN}

\section{A. Metode Penelitian}

Berikut ini adalah flowchart dar penelitian yang dilakukan oleh penulis:

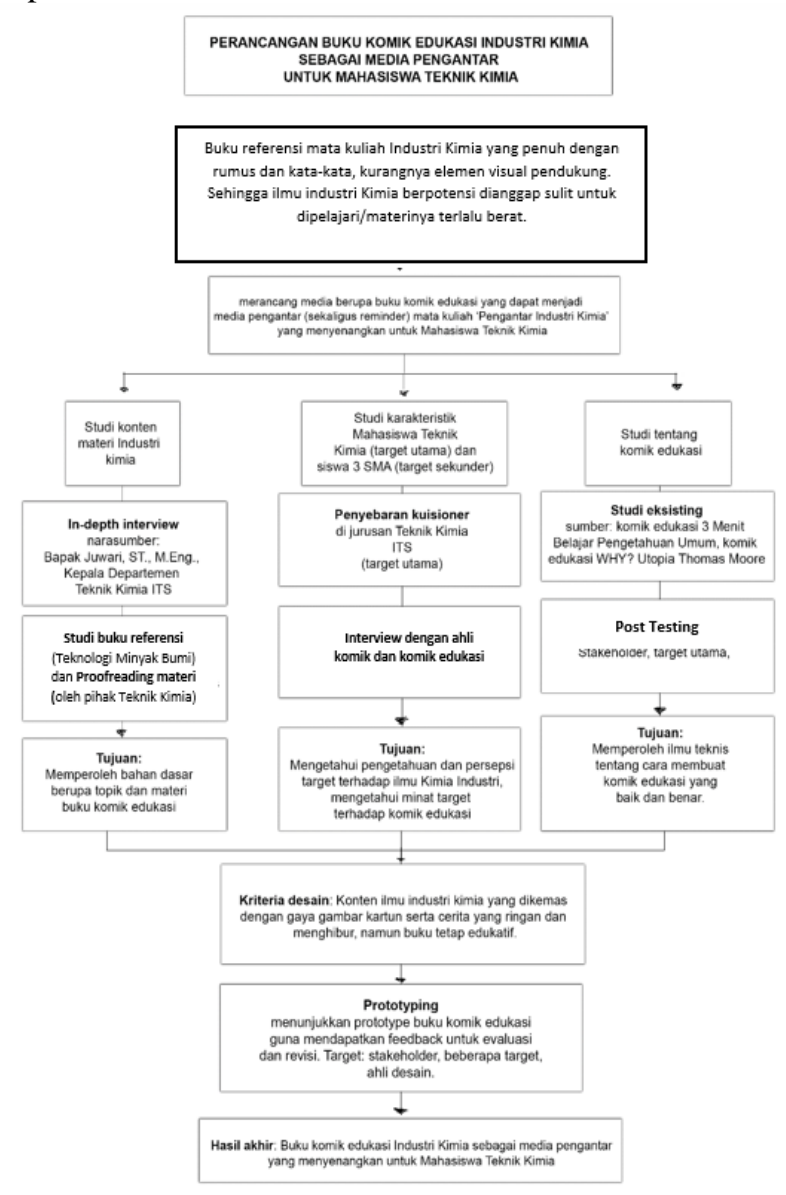

Gambar 1. Bagan penelitian perancangan.

Data diperoleh dengan proses kuesioner yang ditujukan kepada mahasiswa baru Teknik Kimia angakatan 2016 sebanyak 72 responden. Wawancara mendalam dengan Bapak Juwari, ST., M.Eng., PhD selaku stakeholder dan kepala departemen Teknik Kimia ITS dilakukan untuk mengetahui fenomena di lapangan, sumber materi, dan konsep utama dari komik edukasi. Dilakukan pula wawancara dengan Duta Pi selaku praktisi komik dan kak Lia Mega selaku editor dari komik edukasi Pendidikan.id untuk mengetahui kriteria komik yang cocok untuk target audience dewasa muda usia 18-22 tahun. Prototype komik edukasi kemudian diujikan dengan serangkaian proses seperti proof read oleh pihak Teknik Kimia untuk mengecek keabsahan dan akurasi dari materi, serta post 
test untuk mengetahui reaksi, saran, dan kritik target audience terhadap komik ini.

\section{A. Konsep Desain}

Konsep desain menghasilkan konsep karakter, cerita, layout dan metode penyampaian yang dibuat berdasarkan studi eksisting dan studi riset. Konsep dari perancangan ini ialah "Menyenangkan, jelas, dan ringkas".

\section{B. Konsep Metode Penyampaian}

Setelah dilakukan studi riset dan eksisting, ditarik kesimpulan bahwa ada 3 jenis materi utama yang perlu disampaikan. Untuk tiap jenis materi, diperlukan metode yang berbeda. Metode ini mempengaruhi gaya visual, grid, panel, dan layout komik.

\section{Konsep Karakter}

Tiap metode menggunakan karakter yang berbeda. Ada pula tokoh utama dari komik ini adalah 2 mahasiswa.

\section{Konsep Visual}

Konsep visual yang ingin diangkat adalah menggunakan gaya gambar kartun. Hal ini dilakukan untuk mendukung konsep "menyenangkan" dari perancangan.

\section{PEMBAHASAN DESAIN}

\section{A. Metode Penyampaian Komik}

Pada perancangan ini terdapat 3 metode penyampaian komik dapat dilihat Tabel 1.

\section{1) Metode Cerita}

Metode ini digunakan untuk menceritakan plot sampingan (bukan materi pada komik). Plot sampingan berguna sebagai pendukung aspek fun dari komik. Pada perancangan ini, plot sampingan terfokus pada masalah karakter utama. Pada awal cerita ia belum benar memahami ilmu industri kimia minyak bumi, setelah melewati rangkaian pembelajaran, pada akhir cerita ia pun akhirnya menguasai ilmu industri minyak bumi. Plot ini berfokus pada character development.

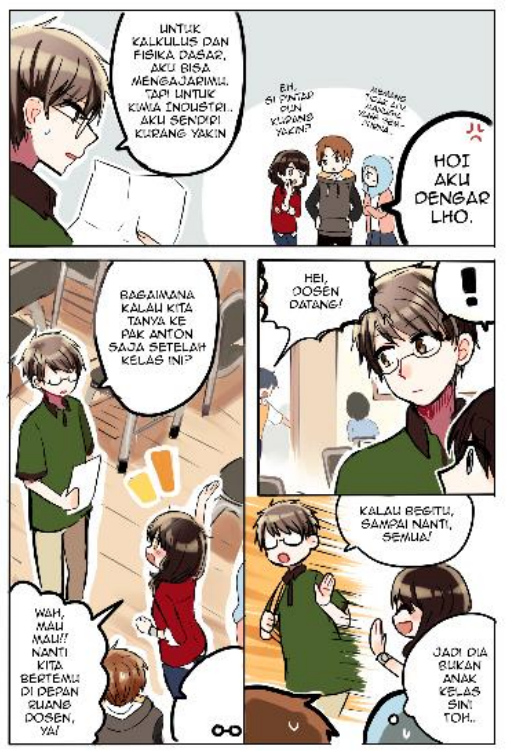

Gambar 2. Contoh penggunaan metode cerita.
Tabel 1.

Perbandingan antara ketiga metode penyampaian

\begin{tabular}{|c|c|c|c|}
\hline $\begin{array}{c}\text { Nama } \\
\text { Metode }\end{array}$ & Metode Cerita & $\begin{array}{c}\text { Metode } \\
\text { Infografis }\end{array}$ & $\begin{array}{c}\text { Metode } \\
\text { Personifikasi }\end{array}$ \\
\hline $\begin{array}{c}\text { Grid } \\
\text { Halaman }\end{array}$ & 3 Grid & 1-2 Grid & 1-2 Grid \\
\hline $\begin{array}{c}\text { Panel } \\
\text { Komik }\end{array}$ & $\begin{array}{l}\text { 3-7 Panel per } \\
\text { halaman. } \\
\text { Panel } \\
\text { cenderung } \\
\text { statis }\end{array}$ & $\begin{array}{l}\text { 1-4 panel } \\
\text { infografis, Panel } \\
\text { dinamis, } \\
\text { menyesuaikan } \\
\text { dengan konsep } \\
\text { infografis }\end{array}$ & $\begin{array}{l}\text { 1-4 panel } \\
\text { berupa } \\
\text { infografis, Panel } \\
\text { dinamis, } \\
\text { menyesuaikan } \\
\text { dengan konsep } \\
\text { infografis }\end{array}$ \\
\hline Pewarnaan & $\begin{array}{l}\text { Pastel, normal } \\
\text { shading, } \\
\text { pencahayaan } \\
\text { normal }\end{array}$ & $\begin{array}{l}\text { Pastel, minim } \\
\text { shading, } \\
\text { Pinggir halaman } \\
\text { (margin) } \\
\text { diblokoleh } \\
\text { warna tertentu } \\
\text { sebagai } \\
\text { penanda } \\
\text { halaman materi }\end{array}$ & $\begin{array}{l}\text { Pastel, basic } \\
\text { cells shading. } \\
\text { Pinggir halaman } \\
\text { (margin) diblok } \\
\text { oleh warna } \\
\text { tertentu sebagai } \\
\text { penanda } \\
\text { halaman materi }\end{array}$ \\
\hline Karakter & $\begin{array}{l}\text { Karakter } \\
\text { utama cerita }\end{array}$ & $\begin{array}{l}\text { Karakter utama } \\
\text { cerita (chibi } \\
\text { atau } \\
\text { sampingan), } \\
\text { dan gambar } \\
\text { tokoh object } \\
\text { atau karakter } \\
\text { penjelas }\end{array}$ & $\begin{array}{l}\text { Personifikasi } \\
\text { dari benda } \\
\text { (senyawa atau } \\
\text { molekul ) atau } \\
\text { tokoh di materi }\end{array}$ \\
\hline $\begin{array}{l}\text { Latar } \\
\text { Komik }\end{array}$ & $\begin{array}{l}\text { Di kampus, di } \\
\text { pabrik (setting } \\
\text { cerita utama } \\
\text { berjalan) }\end{array}$ & $\begin{array}{l}\text { Tidak terikat } \\
\text { latar tertentu, } \\
\text { mengikuti } \\
\text { keperluan } \\
\text { infografis }\end{array}$ & $\begin{array}{l}\text { Tidak terikat } \\
\text { latar tertentu, } \\
\text { mengikuti } \\
\text { keperluan } \\
\text { infografis }\end{array}$ \\
\hline $\begin{array}{l}\text { Dialog } \\
\text { Komik }\end{array}$ & Karakter biasa & $\begin{array}{l}\text { Hanya ada } 1 \\
\text { hingga } 2 \text { dialog } \\
\text { dari tokoh } \\
\text { penjelas, } \\
\text { selebihnya } \\
\text { adalah narasi } \\
\text { informasi } \\
\text { materi }\end{array}$ & $\begin{array}{l}\text { Hanya ada } 1 \\
\text { hingga } 2 \text { dialog } \\
\text { dari tokoh } \\
\text { penjelas, } \\
\text { selebihnya } \\
\text { adalah narasi } \\
\text { informasi } \\
\text { materi }\end{array}$ \\
\hline
\end{tabular}

Karakter pada metode ini ialah karakter-karakter utama pada cerita sampingan. Ada pula berikut adalah desain dari karakter-karakter komik dapat dilihat pada Gambar 3-4.

Sifat dari karakter Rina dibuat berdasarkan riset user persona The Cheerful Student, sementara Dion berdasarkan user Persona The Diligent student. Gaya baju Rina dan Dion mengikuti standar baju perkuliahan (berkerah, bersepatu, rapi). Selain Rina dan Dion, terdapat pula karakter mentor, yaitu karakter yang menjelaskan materi kimia. Karakter mentor tersebut ialah Pak Anton dan Pak Candra. Pak Antony menggunakan baju kemeja yang dibalut jas laboratorium, hal ini dilakukan untuk menggambarkan bahwa beliau adalah salah satu pengajar di tempat Rina dan Dion bersekolah. Sementara, Pak Candra menggunakan seragam refinery coverall safety, karena beliau adalah pekerja pabrik.

Setting dari metode ini juga berdasarkan setting di mana cerita utama berjalan. Ada pula pada komik ini, terdapat 2 setting utama, yaitu kampus dan pabrik minyak bumi.

Referensi untuk latar ruang perkuliahan adalah ruang kelas kampus ITS, hal ini dilakukan agar lebih mudah dalam menggambarkan suasana ruang kelas, sekaligus memberi ciri khas tersendiri pada komik. 


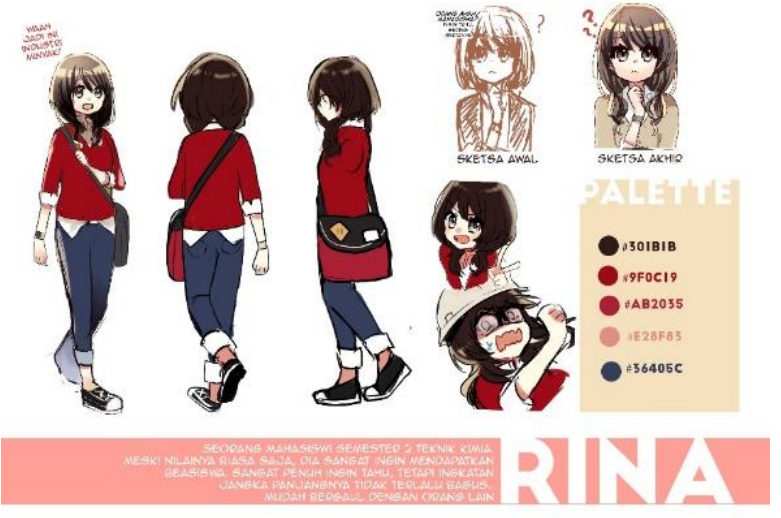

Gambar 3. Desain Karakter Rina.

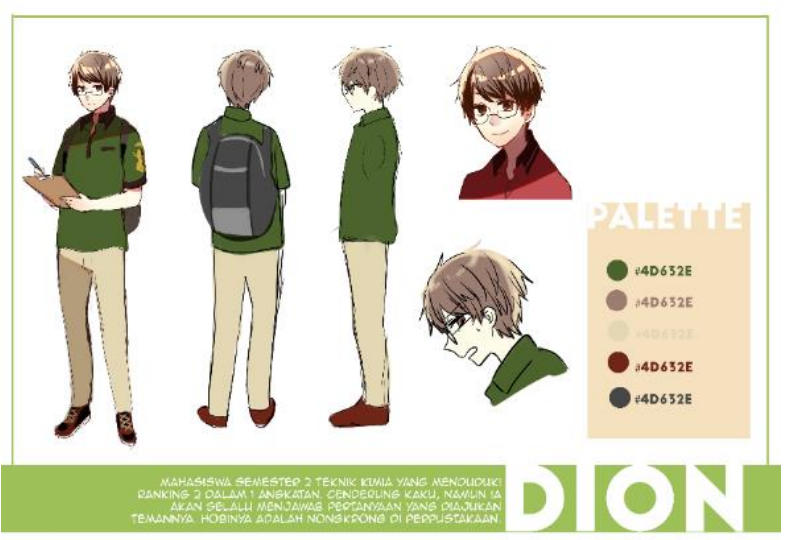

Gambar 4. Desain Karakter Dion.

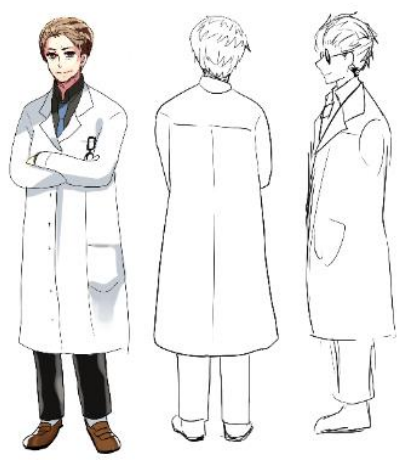

PAK ANTONY

Gambar 5. Desain Karakter Pak Antony.

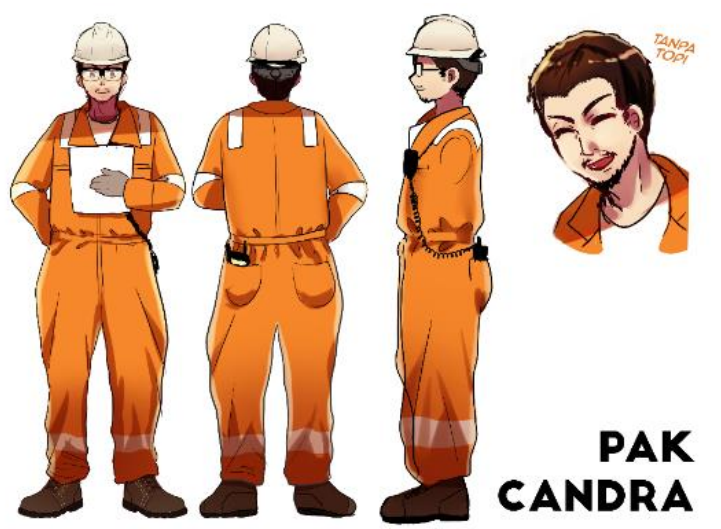

Gambar 6. Desain Karakter Pak Candra.

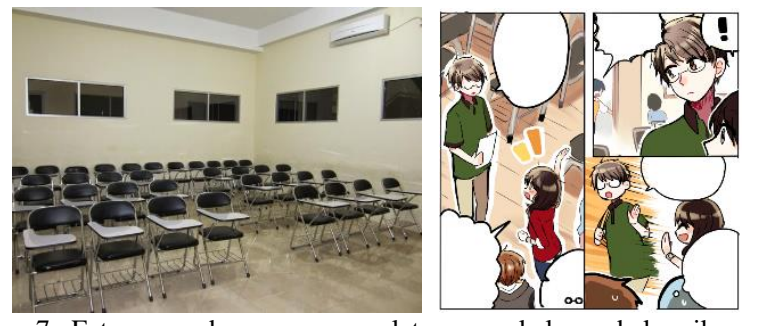

Gambar 7. Foto acuan dan penggunaan latar ruang kelas pada komik.

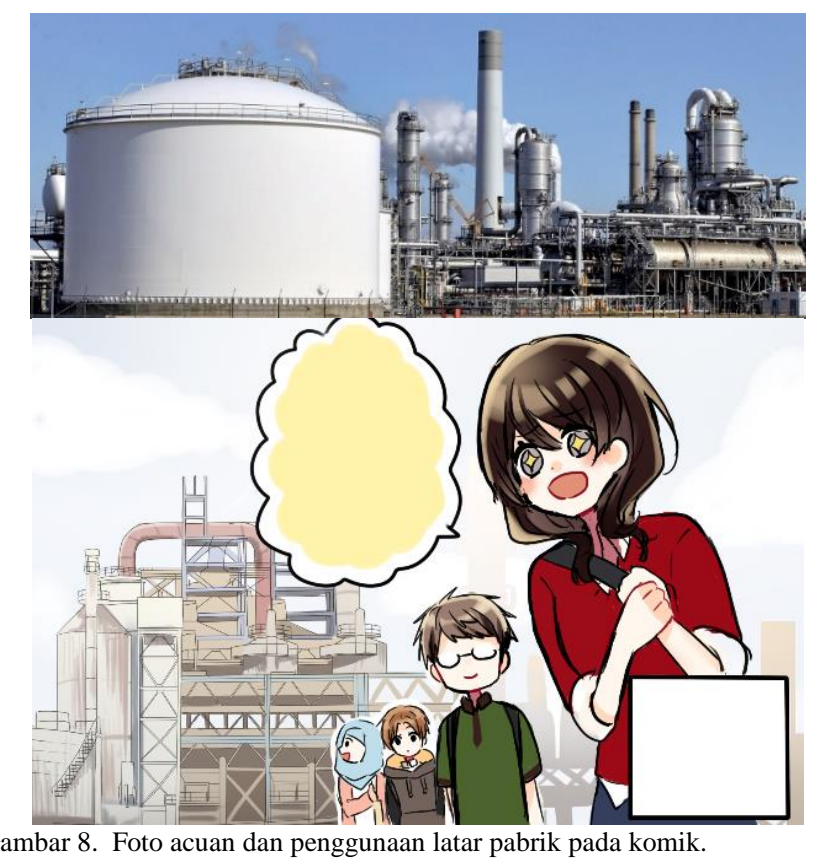

2) Metode Infografis

Metode ini digunakan untuk menyampaikan materi seperti data, table, sejarah, yang tidak melibatkan suatu bahan atau materi tertentu (senyawa, molekul, dan sebagainya.). Karakter pada metode ini ialah stilasi dari tokoh-tokoh atau manusia sesuai dengan materi yang disampaikan.

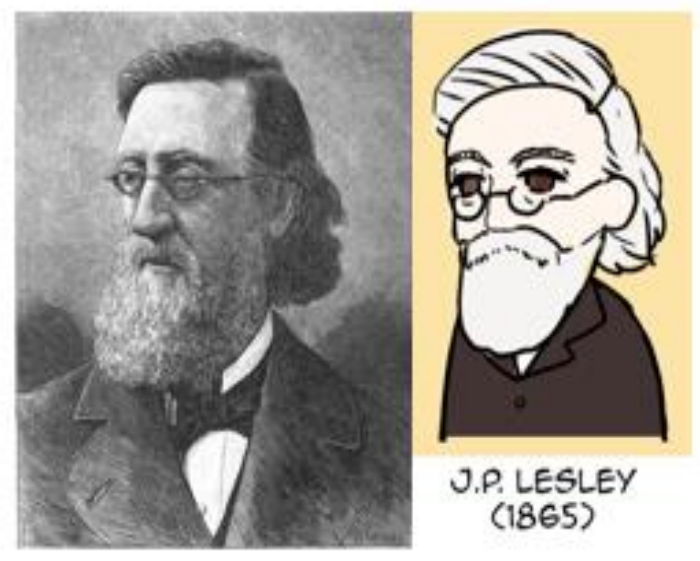

Gambar 9. Contoh stilasi pada metode infografis.

Grid komik ialah 1-2 grid, setting komik tidak pasti karena mengikuti konsep infografis. Tulisan pada metode ini ialah narasi penjelasan materi, dengan 1-2 balon dialog karakter untuk menunjukkan siapa yang menjelaskan materi tersebut. 


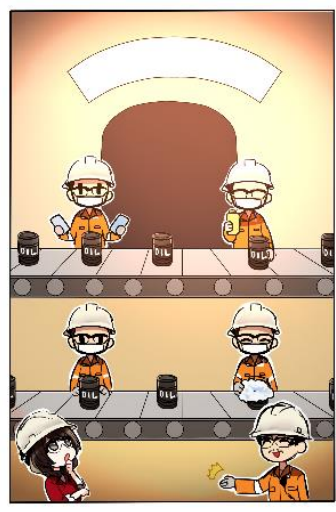

Gambar 10. Contoh penggunaan metode infografis.

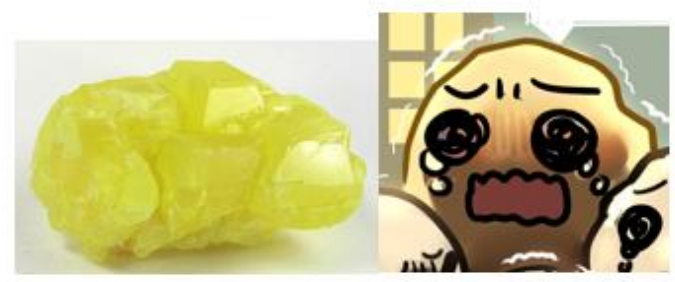

Gambar 11. Contoh karakter personifikasi sulphur.

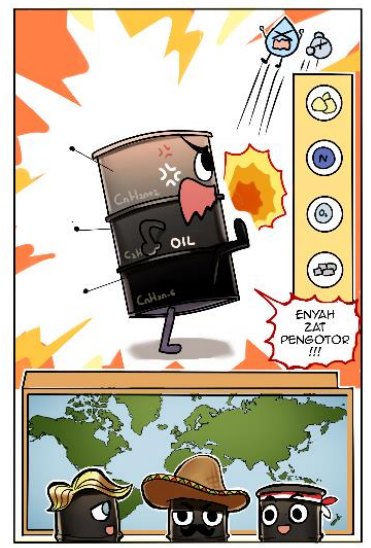

Gambar 12. Contoh penggunaan metode personifikasi.

\section{3) Metode Personifikasi}

Metode ini digunakan menjelaskan karakteristik, sifat, atau informasi mengenai suatu bahan atau materi tertentu (misal senyawa, hidrokarbon, dan sebagainya). Aspek utama dari metode ini ialah karakter, karena menggunakan personifikasi ataupun tokoh representasi dari materi Industri Kimia Minyak Bumi. Tokoh-tokoh ini diciptakan agar penyampaian materi terasa lebih mudah dan diharapkan pembaca jadi lebih cepat memahami serta hafal dengan materi karena tokoh tersebut.

Selain aspek karakter, semua aspek sama seperti di metode infografis.

\section{KESIMPULAN DAN SARAN}

\section{A. Kesimpulan}

Berdasarkan riset penelitian dan pengembangan konsep sebagai solusi desain dari Perancangan Komik Edukasi Industri Kimia "HOW?" dengan sampel "Industri Minyak Bumi" sebagai media Pengantar untuk Mahasiswa Baru Teknik Kimia, maka dapat ditarik beebrapa poin kesimpulan sebagai berikut:

1. Pentingnya sebuah media edukasi yang bersifat menyenangkan belum dapat dipenuhi oleh buku referensi Pengantar Teknik Kimia yang tengah digunakan.

2. Media ini berpeluang untuk terus dikembangkan dan dilengkapi dengan topik-topik kimia industri lainnya seperti industri oleokimia, plastik, dan sebagainya sehingga dapat digunakan mahasiswa baik sebagai hiburan maupun sebagai buku pengantar mata kuliah.

3. Hadirnya komik edukasi ini turut memperkaya literature edukasi Industri Kimia untuk mahasiswa di Indonesia, khususnya mengenai industri minyak bumi.

\section{B. Saran}

Perancangan komik edukasi industri kimia minyak bumi "HOW?" memiliki beberapa hal yang belum disempurnakan penulis sehingga dapat menjadi probabilitas perancangan ke depannya. Hal-hal tersebut antara lain adalah diperlukannya pemasaran lebih lanjut untuk buku komik edukasi Teknik Kimia. Pertimbangan media selain buku juga disarankan, agar penyebaran ilmu lebih luas.

\section{DAFTAR PUSTAKA}

[1] N. Sudjana and A. Rivai, Media Pengajaran: Penggunaan dan Pembuatannya. Bandung: Sinar Baru Algesindo, 2013.

[2] A. Hardjono, Teknologi Minyak Bumi. Yogyakarta: Gadjah Mada University Press, 2015.

[3] T. Yokota, Gakken: Rahasia Keajaiban Alam. Intisari, 2004.

[4] T. Ratnawuri, "Pemanfaatan Komik Strip Sebagai Media Pembelajaran Mahasiswa Pendidikan Ekonomi UM Metro," J. Progr. Stud. Pendidik. Ekon., 2016.

[5] R. Trisno, Volume 8: Belajar Menggambar Komik Jepang. 2008. 